\title{
TSC-22D1 isoforms have opposing roles in mammary epithelial cell survival
}

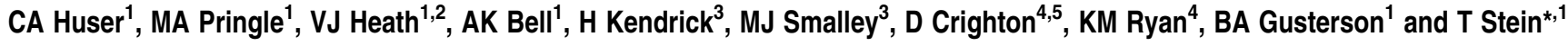

Transforming growth factor $\beta$ (TGF $\beta$ )-stimulated clone-22 domain family member 1 (TSC-22D1) has previously been associated with enhanced apoptosis in several cell systems. In an attempt to identify novel factors that are involved in the control of cell death during mammary gland involution, we found that the mRNA for isoform 2 of TSC-22D1 was highly upregulated $24 \mathrm{~h}$ after forced weaning, when a dramatic increase in cell death occurred, closely following the expression of the known inducer of cell death during involution, TGF $\beta 3$. This was paralleled by strongly increased TSC-22D1 isoform 2 protein levels in the luminal epithelium. In contrast, RNA and protein expression levels of the isoform 1 of TSC-22D1 did not change during development. Whereas isoform 2 induced cell death, isoform 1 suppressed TGF $\beta$-induced cell death and enhanced proliferation in mammary epithelial cell lines. Furthermore, four distinct forms of isoform 2 protein were detected in the mammary gland, of which only a $15-\mathrm{kDa}$ form was associated with early involution. Our data describe novel opposing functions of the two mammalian TSC-22D1 isoforms in cell survival and proliferation, and establish the TSC-22D1 isoform 2 as a potential regulator of cell death during mammary gland involution.

Cell Death and Differentiation (2010) 17, 304-315; doi:10.1038/cdd.2009.126; published online 11 September 2009

The mouse mammary gland provides an excellent model system for studying transcriptional regulation of development. The developmental cycle occurs primarily in the peripubertal animal and comprises several distinct stages, characterised by periods of cellular proliferation, migration, differentiation and apoptosis. ${ }^{1}$ At birth, the mammary fat pad contains a rudimentary ductal structure, which undergoes elongation, branching and differentiation in response to hormonal stimulation throughout puberty and pregnancy. Terminal differentiation occurs during late pregnancy, culminating in the formation of the alveoli, which are responsible for milk secretion during lactation. After weaning, the gland then undergoes a period of extensive cell death and tissue remodelling known as involution, eventually returning to a near pre-pregnant state.

Involution itself comprises two discrete phases. ${ }^{2,3}$ The first phase is induced by milk stasis and local factors, and is characterised by a widespread apoptosis of individual secretory epithelial cells, ${ }^{4,5}$ paralleled by the phagocytic clearance of these cells. ${ }^{6}$ This phase is reversible for up to 2 days, as lactation can be reinitiated by renewed suckling. ${ }^{5}$ After this time, involution enters the second, irreversible, stage. This final phase of the developmental cycle is distinguished by a widespread remodelling of the gland, and is driven by reduced levels of systemic hormones, which seem to act as survival factors, and increased expression of matrix metalloproteinases. ${ }^{2,5}$

We have recently used oligonucleotide microarray technology to create a database of gene expression profiles throughout mouse mammary gland development. This study identified 96 RNAs that showed specific increased abundance after forced weaning. ${ }^{3,7}$ These RNAs included many factors that had previously been associated with involution, including STAT3 (signal transducer and activator of transcription 3), ${ }^{8}$ $\mathrm{C} / \mathrm{EBP} \delta$ (CCAAT enhancer binding protein $\delta$ ), ${ }^{9}$ Bax (Bcl2associated X-protein) ${ }^{10}$ and transforming growth factor $\beta 3$ (TGF $\beta 3$ ). ${ }^{11}$ However, many of these RNAs had not been described previously to function during involution and could therefore represent novel regulators of cell death in the mammary gland. Among these RNAs was the transcription factor TGF $\beta$-stimulated clone-22 (TGF $\beta$-stimulated clone-22 domain family member 1 (TSC-22D1), also known as TGFb1i4).

TSC-22D1, a member of the leucine zipper superfamily, was initially characterised as a gene induced in culture by a number of growth factors, including TGF $\beta 1 .{ }^{12}$ It is highly conserved at both the mRNA and protein levels, and found in a range of organisms, from nematodes ${ }^{13}$ to flies, ${ }^{14}$ birds, ${ }^{15}$ fish, ${ }^{16}$ amphibians $^{17}$ and mammals. ${ }^{12,18}$ Previous studies have determined that TSC-22D1 is involved in epithelial

${ }^{1}$ Division of Cancer Sciences and Molecular Pathology, University of Glasgow, Glasgow, UK; ${ }^{2}$ Now at Nature Publishing Group, the Macmillan Building, 4 Crinan Street, London N1 9XW, UK; ${ }^{3}$ Breakthrough Breast Cancer Research Centre, The Institute of Cancer Research, London, UK; ${ }^{4}$ Tumour Cell Death Laboratory, CRUK Beatson Institute for Cancer Research, Glasgow, UK and ${ }^{5}$ Now at Cancer Research Technology, CRUK Beatson Institute for Cancer Research, Glasgow, UK

*Corresponding author: T Stein, Division of Cancer Sciences and Molecular Pathology, University of Glasgow, Western Infirmary, Dumbarton Road, Glasgow G11 6NT, UK. Tel: + 440141211 1942; Fax: + 440141337 2494; E-mail: T.Stein@ clinmed.gla.ac.uk

Keywords: TSC-22 isoforms; involution; mammary gland; apoptosis; proliferation

Abbreviations: bun, bunched; FACS, fluorescence-activated cell sorting; GFP, green fluorescent protein; kDa, kilodalton; KRT, cytokeratin; miRNA, micro RNA; qRT-PCR, quantitative reverse transcriptase-polymerase chain reaction; TGF $\beta$, transforming growth factor $\beta$; TGFb1i4, TGF $\beta 1$-induced clone 4 ; TSC-22D1, TGF $\beta$-stimulated clone-22 domain family member 1

Received 19.11.08; revised 27.7.09; accepted 30.7.09; Edited by DR Green; published online 11.9.09 
morphogenesis, ${ }^{19}$ differentiation, ${ }^{20,21}$ cell growth ${ }^{22}$ and in the regulation of cell death. ${ }^{18,21,23}$ TSC-22D1 was found to be expressed in regions of epithelial-mesenchymal interaction, ${ }^{19}$ and cellular differentiation. ${ }^{24,25}$ Furthermore, TSC22D1 has a wide tissue distribution, both in embryonic development and in adults, including the heart, lung, kidney, stomach, intestine, prostate, ovary, brain, and endothelium of blood vessels. ${ }^{26,27}$ The mammalian TSC-22D1 gene encodes two isoforms, ${ }^{26} 1$ and 2 , which have different $\mathrm{N}$ termini, but share the TSC box, which binds DNA, ${ }^{28}$ and the leucine zipper-like domain, which serves as a dimerisation interface ${ }^{29}$ and regulates transcriptional activity. ${ }^{23}$

In this study, we show that TSC-22D1 is expressed in the mouse mammary gland, and that the two TSC-22D1 isoforms have different expression profiles during mammary gland development. Furthermore, we demonstrate opposing functions of the two TSC-22D1 isoforms on cell cycle and survival in vitro. Whereas TSC-22D1 isoform 2 induces cell death and can be upregulated by TGF $\beta 3$ treatment, isoform 1 reduces TGF $\beta 3$-induced cell death, enhances proliferation and is unresponsive to TGF $\beta$. Therefore, we propose that induction of the TSC-22D1 isoform 2 may act downstream of TGF $\beta 3$ signalling to initiate cell death during early mouse mammary gland involution.

\section{Results}

TSC-22D1 is expressed during the apoptotic stage of early involution. We previously published a mouse mammary gland development microarray database in which we identified mRNAs specifically upregulated during mammary gland involution. ${ }^{3,7}$ Among these was the transcription factor TSC-22D1, a member of the leucine zipper superfamily. ${ }^{12}$ Expression of TSC-22D1 was fairly constant in virgin mice and throughout early pregnancy (Figure 1). However, a gradual decline in the mRNA level was observed after day 14.5 of pregnancy, reaching a low at day 7 of lactation. After forced weaning, abundance of TSC22D1 mRNA was dramatically increased during the early apoptotic phase of involution and remained high until the third day after pup removal, after which time the level diminished. By day 20 of involution, the TSC-22D1 message had essentially returned to the baseline level, similar to that observed in the virgin state. The TSC-22D1 mRNA expression profile therefore mimicked that of several genes that are closely linked with the induction of apoptosis in the mammary gland (Figure 1).

Different expression patterns for the two TSC-22D1 isoforms. The Affymetrix microarray probe set (Affymetrix, High Wycombe, UK) was unable to distinguish between the two isoforms of TSC-22D1. To identify which of the two isoforms showed increased abundance during involution and to compare their profiles during the pregnancy cycle, we performed isoform-specific quantitative reverse transcriptase-PCR (qRT-PCR). Only the mRNA of the TSC-22D1 isoform 2 was strongly increased at the start of involution and had a similar profile to the Affymetrix microarray data (Figure 2a). In contrast, the abundance of isoform 1 mRNA was constantly low during the entire pregnancy cycle.

To establish whether the changes in RNA abundance were also reflected by the changes at the protein level, we performed western blotting of mammary gland extracts from all stages of development. The theoretical sizes for the two isoforms were 110 (isoform 1) and $15.5 \mathrm{kDa}$ (isoform 2), respectively. A $\sim 110-k D a$ band, which could be blocked with the antigen (Supplementary Figure 1a), was detectable with a pan TSC-22D1 antibody throughout development (Figure $2 b-d$ ), and corresponded to the band found when the TSC-22 isoform 1 was overexpressed in MCF7 cells (left-hand lane).

The isoform 2 of TSC-22D1 was detected as four distinct bands by western blotting, of $\sim 11,15,18$ and $20 \mathrm{kDa}$, respectively, in size that showed different expression profiles during mammary gland development (Figure $2 \mathrm{~b}$ ). The largest 20-kDa band was faintly detected during pregnancy, peaking at day 14.5 , but its levels diminished thereafter and remained absent during involution. The 18-kDa band could be detected at the end of pregnancy, at the beginning of lactation and

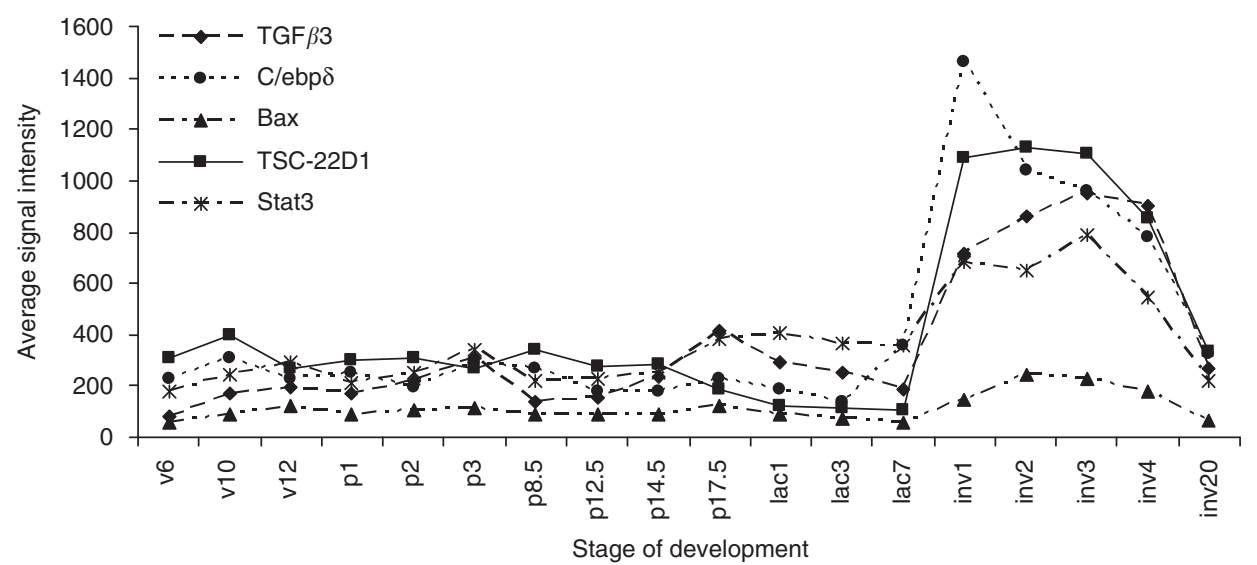

Figure 1 TSC-22D1 expression coincides with apoptosis during mammary gland development. RNA expression levels of TSC-22D1 and other known cell death inducers during involution as determined by Affymetrix Microarray analysis. The graphs represent averages \pm S.E.M. from three individual mice for each time point. $v=$ virgin, time in weeks, $p=$ pregnancy, lac = lactation, inv = involution, time in days 
a

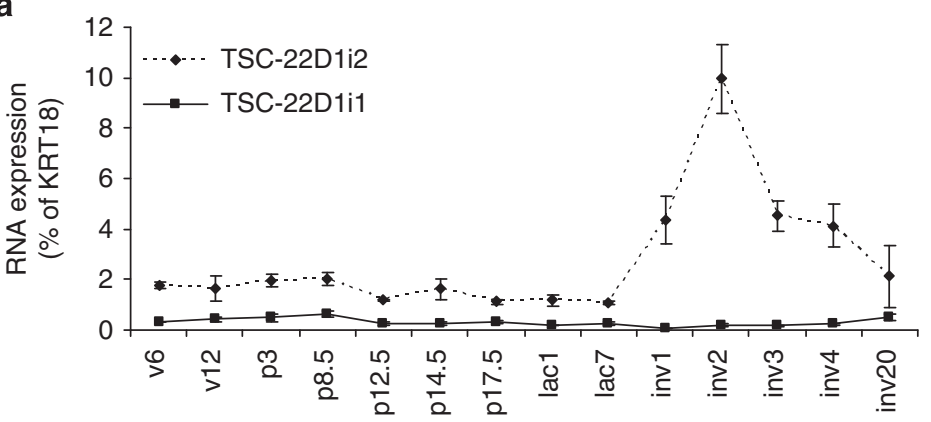

Stage of development

b

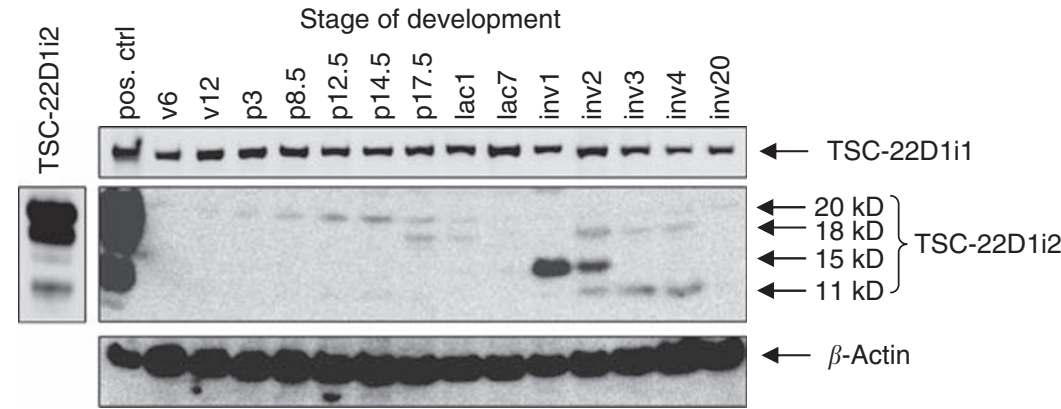

C

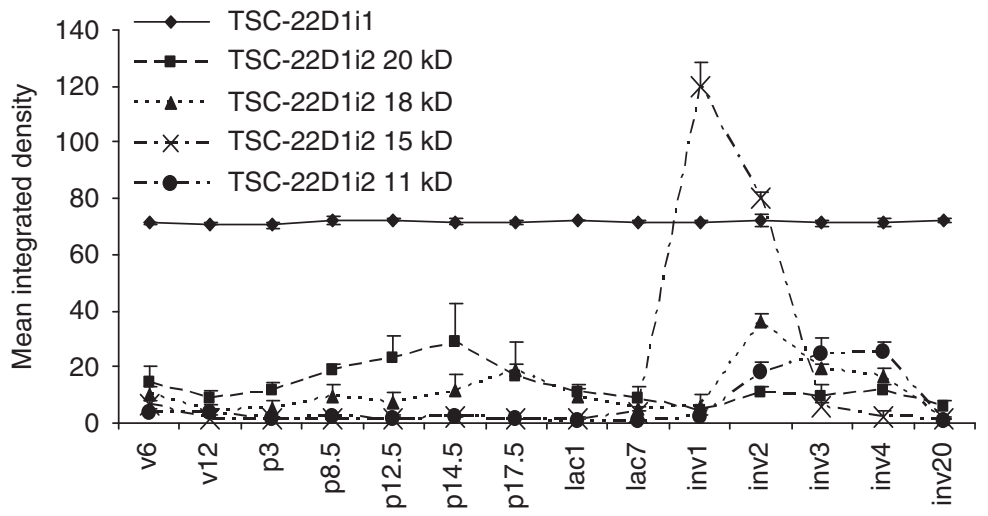

Stage of development

d

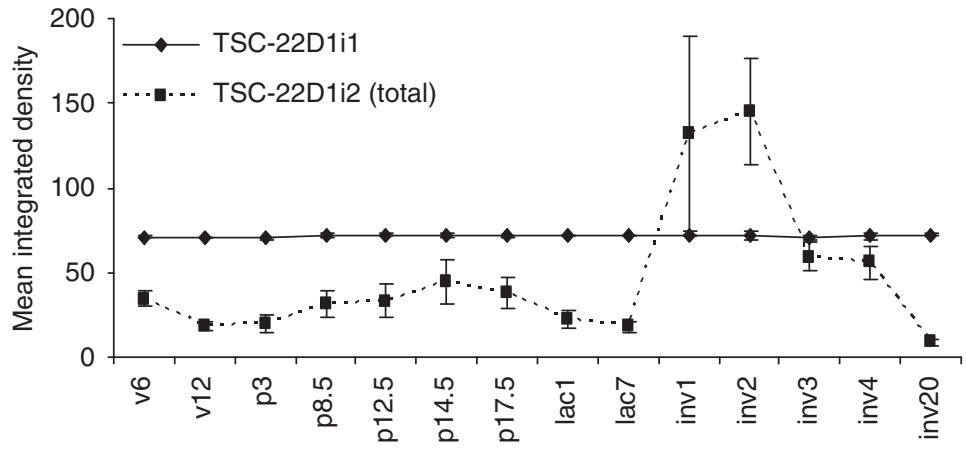

Stage of development

Figure 2 Differential expression of the two TSC-22D1 isoforms. (a) mRNA expression levels of TSC-22D1 isoforms 1 (black line) and 2 (broken line) as determined by qRT-PCR, using cytokeratin-18 (KRT-18) as the epithelial housekeeping gene. Data represent average \pm S.E.M., $N=3$ mice at each time point. (b) Western blot showing TSC-22D1 isoform 1 ( 1 band) and 2 ( 4 bands) protein levels as detected with a pan TSC-22D1 antibody (Proteintech) during mammary gland development. $v=$ virgin, time in weeks, $p=$ pregnancy, lac = lactation, inv = involution, time in days. (c) Densitometric analysis of three independent western blots from independent protein extracts and mice. Each band for TSC-22D1 isoform 2 is represented separately. Data represent average \pm S.E.M. (d) Densitometric analysis of three independent western blots from independent protein extracts and mice. The mean integrated density for the TSC-22D1 isoform 2 bands is summed, and represent the total expression. Data represent average \pm S.E.M. 

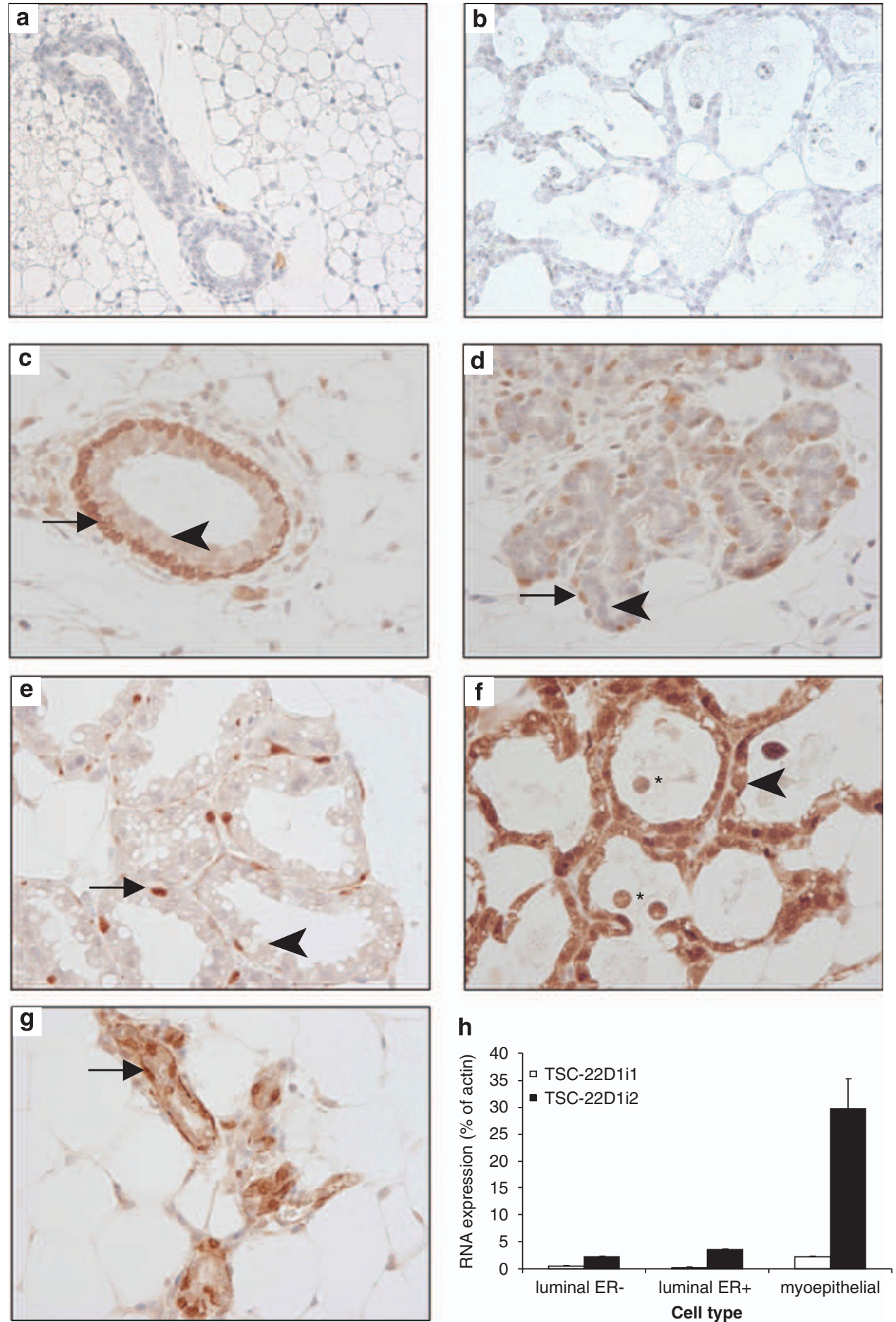

Figure 3 TSC-22D1 localisation in the mammary gland epithelium. IHC for TSC-22D1 during various stages of the mammary gland development; magnifications: $(\mathbf{a}$ and $\mathbf{b}) \times 200,(\mathbf{c}-\mathbf{g}) \times 400$. (Panel a) Negative control of primary duct in a virgin (12 weeks) mammary gland. (Panel b) Negative control of involuting mammary gland ( 2 days). (Panel c) Primary duct in a virgin (12 weeks) mammary gland. (Panel d) Mid-pregnant (14.5 days) mammary gland showing the formation of multi-lobular alveoli. (Panel e) Lactating (7 days) mammary gland, displaying the fully differentiated organ with milk-filled lumens. (Panel f) Involuting mammary gland (2 days) displaying strong staining for TSC-22D1 in the luminal cells (arrowhead) and dying cells shed into the lumen (*). (Panel g) Involuting mammary gland (10 days), returning to a pre-pregnant-like architecture. (Panels $\mathrm{c}-\mathrm{g}$ ) Arrow shows outer layer of myoepithelial cells, and arrowhead shows the inner layer of luminal cells. (h) TSC-22D1 isoform 1 (white bars) and isoform 2 (black bars) mRNA expression levels in primary mammary epithelial cells from a 10-week-old virgin gland sorted by cell type, according to CD24 and CD45 and Sca-1 expression. Bars represent averages \pm S.E.M., $N=3$ 

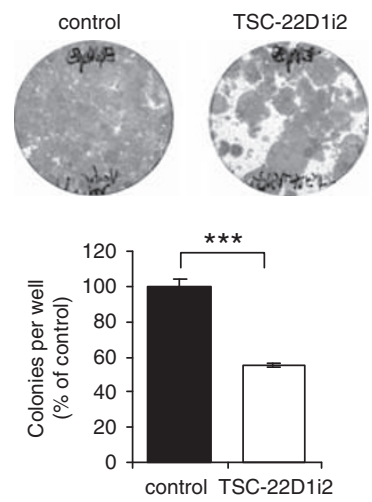

b

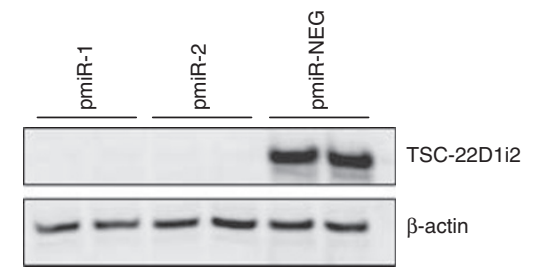

C
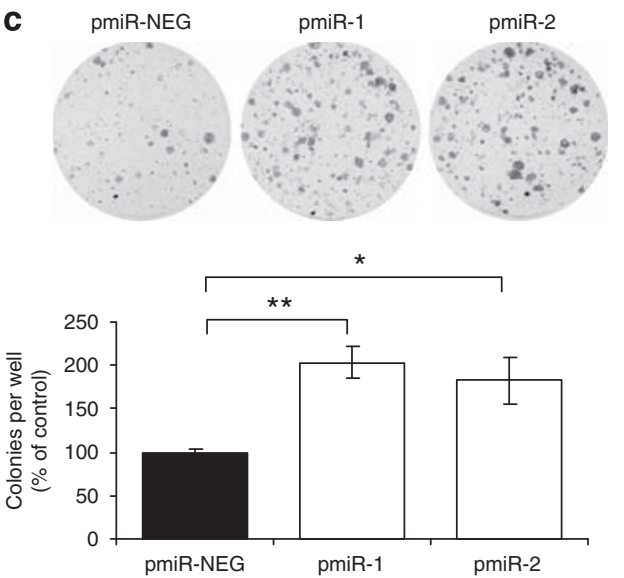

d
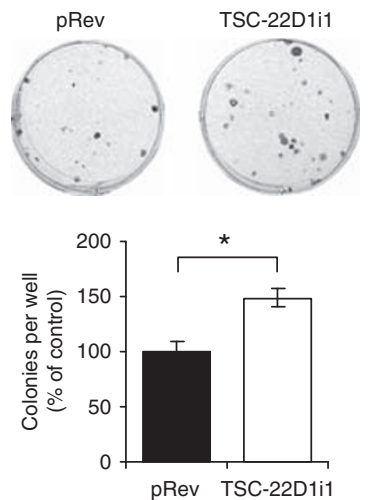

e

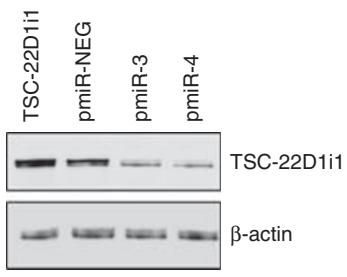

f
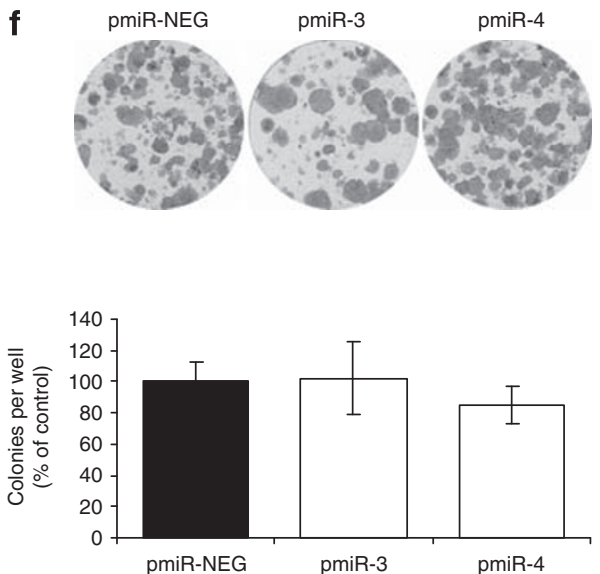

Figure 4 Effect of TSC-22D1 isoforms on colony formation. (a) EpH4 cells transfected with a control plasmid (pCMV-Sport6 plus pSV2Neo) or with TSC-22D1 isoform 2 plus pSV2Neo were grown in the presence of $1 \mathrm{mg} / \mathrm{ml} \mathrm{G418.} \mathrm{Colonies} \mathrm{were} \mathrm{stained} \mathrm{with} \mathrm{Giemsa} \mathrm{and} \mathrm{counted.} \mathrm{(b)} \mathrm{TSC-22D1} \mathrm{isoform} 2$ knockdown using miR plasmids. Cells were transfected with TSC-22D1 isoform 2 together with pmiR-NEG, pmiR-1 or pmiR-2. Cell lysates were extracted and western blotting was performed using pan-TSC-22 antibody (Proteintech). (c) EpH4 cells transfected with pmiR-NEG, pmiR-1 or pmiR-2 and grown in the presence of $6 \mu \mathrm{g} / \mathrm{ml}$ blasticidine. Colonies were stained with Giemsa and counted. (d) EpH4 cells were transfected with pTSC-22D1 isoform 1 cloned in the correct (pTSC-22D1i1) or inverse (pRev) orientation, and grown in the presence of $1 \mathrm{mg} /$ ml G418. (e) TSC-22D1 isoform 1 knockdown using miR plasmids. Cells were transfected with TSC-22D1 isoform 1 together with pmiR-NEG, pmiR-3 or pmiR-4. Cell lysates were extracted and western blotting was performed using pan-TSC-22 antibody (Proteintech). (f) EpH4 cells transfected with pmiR-NEG, pmiR-3 or pmiR-4 and grown in the presence of $6 \mu \mathrm{g} / \mathrm{ml}$ blasticidine. Bars for all experiments represent the average percent of colonies normalised to the controls, which are represented as $100 \%$, \pm S.E.M, $N=3 .{ }^{*} P<0.05,{ }^{* \star} P<0.01,{ }^{* \star *} P<0.001$. Photographs are representative cell culture dishes from these three independent experiments

again at days $2-4$ of involution. The $15-\mathrm{kDa}$ band was the most predominant band, and was only detectable at days 1 and 2 of involution, whereas the $11-\mathrm{kDa}$ band was only detectable at days 2-4 of involution. This pattern was consistently detected with two commercially available independent polyclonal antibodies (R\&D, Abingdon, UK, made in goat and Proteintech Group, Manchester, UK, made in rabbit) in three independent protein sets, and all bands could be blocked by pre-incubation with the recombinant TSC-22D1 isoform 2 protein (Supplementary Figure 1b). All bands corresponded to bands found when the TSC-22D1 isoform 2 was overexpressed from a cDNA clone in MCF7 cells
(Figure 2b, left-hand panel), indicating that they are all derived from the same transcript. Therefore, the different bands do not represent different splice variants, but probably represent post-translational modifications of the TSC-22D1 isoform 2, with or without the use of different translational start sites. The $15-\mathrm{kDa}$ band was the weakest of the four bands in the control samples, but was the dominant band during involution, indicating a particular role of this form of the TSC-22D1 isoform 2 during the early stage of involution.

The average densitometry data for each band indicates that the expression pattern of each TSC-22D1 isoform 2 band is distinct and reproducible (Figure $2 \mathrm{c}$ ). In addition, when the 

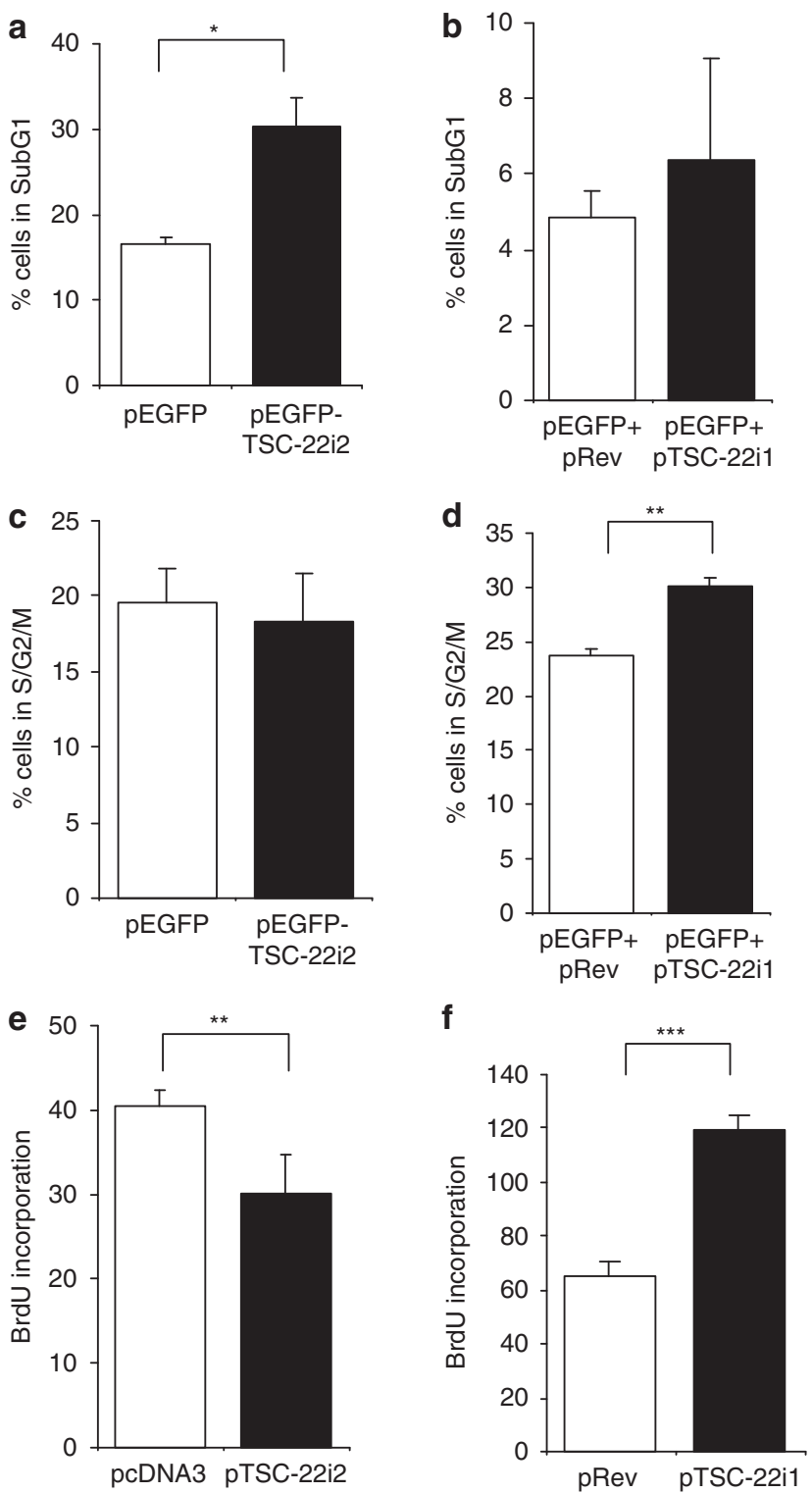

Figure 5 Effect of TSC-22D1 isoforms on cell death and proliferation. (a, c) EpH4 cells were transfected with a pEGFP or pEGFP-TSC-22 isoform 2. After $72 \mathrm{~h}$, the cells were stained with propidium iodide and analysed by flow cytometry for (panel a) sub-G1 peak (cell death) and (panel c) S/G2/M peak (proliferation). (b, d) $\mathrm{EpH} 4$ cells were transfected with pEGFP and either $\mathrm{pTSC}-22 \mathrm{D} 1$ isoform 1 cloned in the reverse (pRev) or correct orientation (pTSC-22i1) for $24 \mathrm{~h}$, then stained with propidium iodide and analysed by FACS flow cytometry for (panel b) sub-G1 peak and (panel d) S/G2/M. Bars represents the average percentage of cells in each peak, \pm S.E.M, $N=3$. (e) EpH4 cells were transfected with pcDNA3 or pTSC-22D1 isoform 2, and proliferation measured by BrdU assay after $24 \mathrm{~h}, N=8$. (f) $\mathrm{EpH} 4$ cells were transfected with pTSC-22 isoform 1 cloned in the reverse or correct orientation, and proliferation was measured by BrdU incorporation after $24 \mathrm{~h}, N=8$. ${ }^{\star} P<0.05,{ }^{* \star} P<0.01,{ }^{* \star *} P<0.001$

densitometry for all the TSC-22D1 isoform 2 bands are summed up (Figure 2d), the pattern of expression is remarkably similar to the mRNA expression data shown in Figure 2a.

Further evidence for the association of the TSC-22D1 isoform 2 with mammary gland involution and accompanied cell death came from a previously established in vitro involution model. ${ }^{30}$ In this study, the TSC-22D1 isoform 2 mRNA expression was dramatically increased on hormone withdrawal and induction of cell death, whereas isoform 1 expression was unaltered and only detected at low levels throughout the experiment (data not shown), thereby reflecting the in vivo microarray data.

Altered localisation of TSC-22D1 during involution. TSC-22D1 was not previously described in the mammary gland. Therefore, we used immunohistochemistry (IHC) on paraffin-embedded sections of all developmental stages of the pregnancy cycle to establish which cells of the mammary gland expressed TSC-22D1. All available antibodies react with both isoforms. The negative control without the primary antibody showed no staining (Figure $3 a$ and $b$ ). Expression of the TSC-22D1 protein in the mammary gland of the virgin, pregnant and lactating mouse was both nuclear and cytoplasmic, and was primarily detected in myoepithelial cells of the ducts and alveoli (Figure $3 c-e$, respectively). However, the staining for TSC-22D1 was strongly increased in the early involuting secretory luminal epithelium, where the expression was again nuclear and cytoplasmic (Figure 3f). In addition, TSC-22D1 was present in the cells, which had been shed from the epithelium into the lumen (Figure $3 f$, asterisk $\left(^{\star}\right)$ ). After 10 days of involution, the localisation of TSC-22D1 started to return to a pre-pregnant pattern (Figure $3 \mathrm{~g}$ ). All staining could be blocked by absorption with the recombinant TSC-22D1 isoform 2 protein (Supplementary Figure 2).

As no currently available antibodies are able to distinguish between the two isoforms, we performed qRT-PCR on RNA from primary mammary epithelial cells of 12-week-old virgin mice, sorted according to CD24, CD45 and Sca-1 expression as described previously. ${ }^{31,32}$ These markers allow the discrimination between ER-positive and ER-negative luminal epithelial, as well as myoepithelial cells, and expression of the correct cell type-specific marker genes has been recently published. ${ }^{31,32}$ The qRT-PCR data confirmed that both TSC22D1 isoforms were preferentially expressed in myoepithelial cells (CD2 $4^{\text {low }}$ ) of the virgin adult mammary gland (Figure $3 \mathrm{~h}$ ), with isoform 2 showing a significantly higher mRNA expression than does isoform 1. The combined results from $\mathrm{IHC}$, qRT-PCR and western blots therefore suggest that both TSC-22D1 isoforms are expressed in the mammary gland myoepithelium, but that the increased luminal expression of TSC-22D1 protein observed during involution is due to an increase in isoform 2.

TSC-22D1 isoforms show opposite effects on colony formation potential in vitro. The TSC-22D1 isoform 2 is reported to induce growth arrest and cell death in several in vitro systems ${ }^{18,23,33}$ and in a recent knockout model. ${ }^{34}$ Recently, different variants of the Drosophila orthologue of TSC-22 domain proteins, bunched (bun) or shortsighted, have been reported to exert opposing effects on proliferation and cell growth. ${ }^{35,36}$ Therefore, we tested the effect of the two TSC-22D1 isoforms on the colony formation potential of the non-malignant mammary epithelial cell line $\mathrm{EpH} 4$ in vitro. $\mathrm{EpH} 4$ cells were transfected with either a TSC-22D1 isoform 2 expression plasmid or a control vector, together with a neomycin resistance gene. These were grown in the 


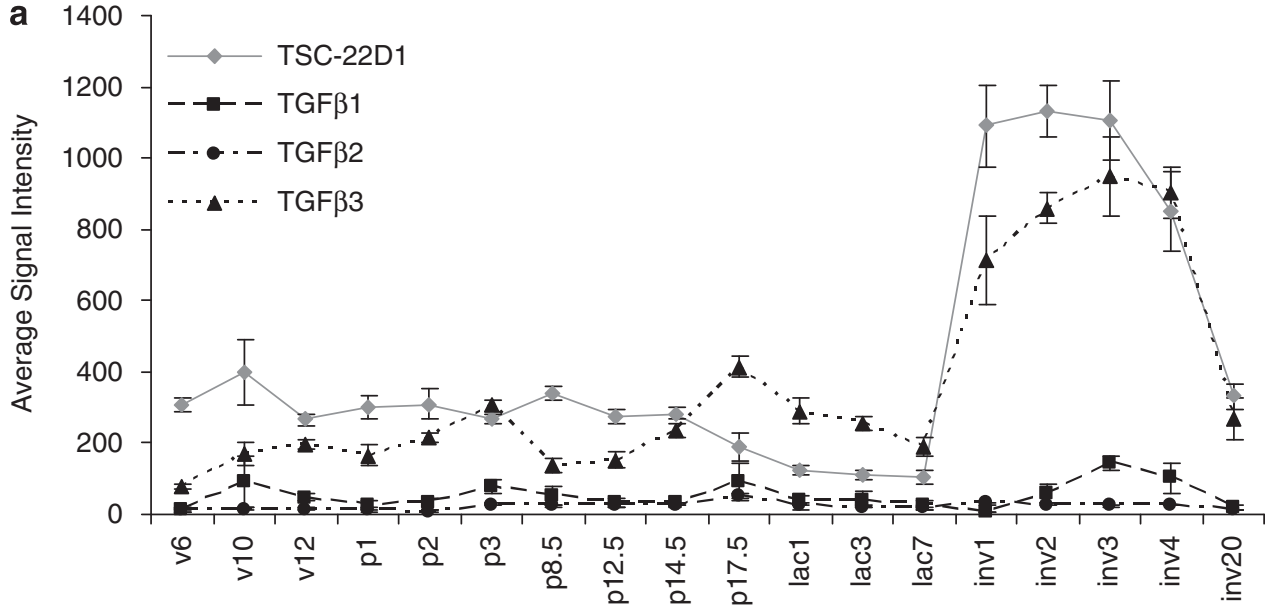

Stage of development

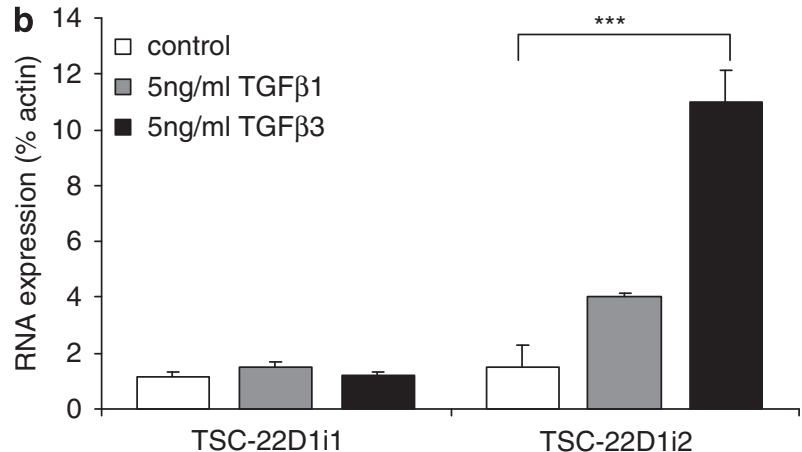

Figure 6 Association between TSC-22D1 and TGF $\beta 3$. (a) mRNA expression profiles of TSC-22D1, TGF $\beta 1$, TGF $\beta 2$ and TGF $\beta 3$ during mammary gland development, as determined by Affymetrix Microarray analysis. Data are averages \pm S.E.M., $N=3$. (b) qRT-PCR of TSC-22D1 isoforms 1 and 2 expression levels in response to vehicle (white bars), $5 \mathrm{ng} / \mathrm{ml}$ TGF $\beta 1$ (grey bars) or $5 \mathrm{ng} / \mathrm{ml} \mathrm{TGF} \beta 3$ (black bars) treatment for $2 \mathrm{~h}$. Bars represent averages \pm S.E.M., $N=3,{ }^{\star \star *} P<0.001$

presence of G418 and surviving colonies were stained with Giemsa staining solution. Those cells transfected with isoform 2 showed reduced colony formation potential compared with the control vector (Figure 4a). In addition, when the TSC-22D1 isoform 2 was specifically knocked down using plasmids expressing two TSC-22D1 isoform 2specific micro RNA (miRNA) constructs (Figure 4b), the colony formation potential was increased (Figure 4c), indicating that the TSC-22D1 isoform 2 negatively affects cell survival and/or proliferation in a mammary epithelial cell line.

In contrast, when isoform 1 was transfected into $\mathrm{EpH} 4$ cells, increased colony formation was detected (Figure 4d), indicating that the two isoforms of TSC-22D1 exert opposite effects on cell survival and/or proliferation. A specific knockdown of the TSC-22D1 isoform 1 did not affect the number or size of the colonies formed (Figure $4 \mathrm{e}$ and $\mathrm{f}$ ), indicating that the TSC22D1 isoform 1 can promote, but is not necessary for survival and/or proliferation of $\mathrm{EpH} 4$ cells using this assay.

TSC-22D1 isoforms show opposite effects on proliferation and apoptosis. To confirm our colony formation assay results, and to investigate whether the two TSC-22D1 isoforms regulate proliferation and apoptosis similarly to their
Drosophila orthologues in a mammary epithelial cell system, we analysed transfected $\mathrm{EpH} 4$ cells by fluorescence-activated cell sorting (FACS). The TSC-22D1 isoform 2 significantly increased the percentage of $\mathrm{EpH} 4$ cells found in the sub-G1 phase, indicating increased cell death (Figure 5a), whereas no growth arrest in the form of a concomitant increase in the G1 phase was observed (data not shown). In contrast, the TSC-22D1 isoform 1 did not significantly affect the percentage of cells in the sub-G1 phase (Figure $5 b$ ).

Furthermore, although there was no change in the amount of cells in the S/G2/M-phase when isoform 2 was overexpressed (Figure $5 c$ ), the TSC-22D1 isoform 1 overexpression increased the percentage of cells in the S/G2/M-phase (Figure 5d), suggesting an increase in proliferating cells. These results were confirmed using a BrdU incorporation assay (Figure 5e and f). Therefore, our data show that the two isoforms of TSC-22D1 have opposing functions on proliferation and survival in mammary epithelial cells.

TGF $\beta 3$ can induce the TSC-22D1 isoform 2 in mammary epithelial cells. TSC-22D1 was originally identified as a gene induced by TGF $\beta 1$ in mouse osteoblastic cells. ${ }^{12}$ Moreover, a large body of evidence indicates that TGF $\beta$ signalling influences several stages of mammary gland 
a

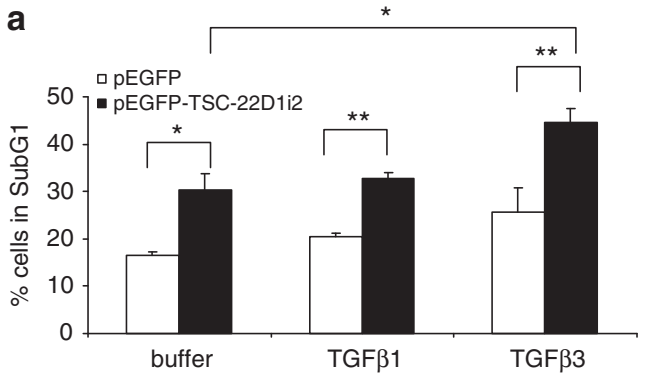

C

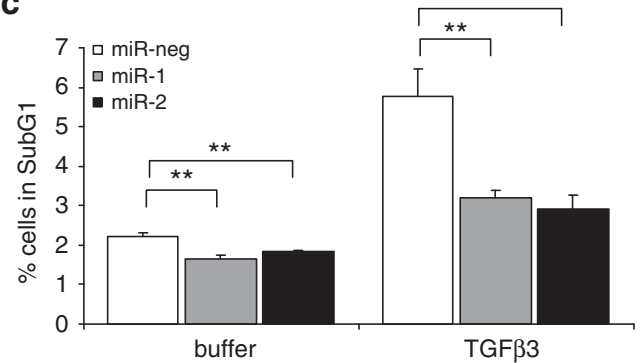

b

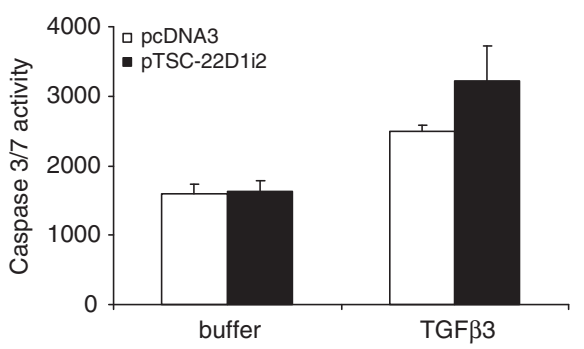

d

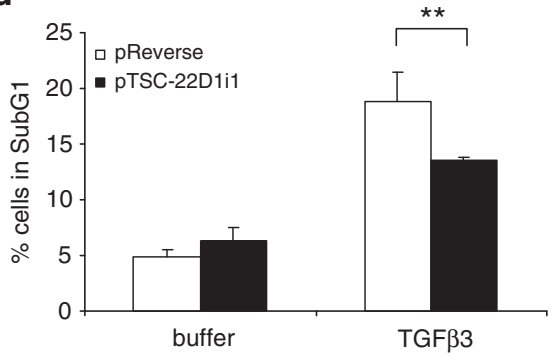

Figure 7 Effect of TSC-22D1 on TGF $\beta 3$-induced cell death. (a) EpH4 cells were transfected with pEGFP or pEGFP-TSC-22D1 isoform 2, and treated with buffer, $5 \mathrm{ng} / \mathrm{ml}$ TGF $\beta 1$ or $5 \mathrm{ng} / \mathrm{ml} \mathrm{TGF} \beta 3$ for $72 \mathrm{~h}$. Cells were then collected and analysed by FACS for sub-G1 peak. Bars represent mean \pm S.E.M., $N=3$. (b) EpH4 cells were transfected with pcDNA3 or pTSC-22D1 isoform 2 and treated with buffer or $5 \mathrm{ng} / \mathrm{ml} \mathrm{TGF} \beta 3$, and the caspase $3 / 7$ activity measured after $18 \mathrm{~h}$. Bars represent mean \pm S.E.M., $N=3$. (c) $\mathrm{EpH} 4$ cell lines stably overexpressing miRNAs targeted against TSC-22D1 isoform 2 under doxycycline control were treated with vehicle or $5 \mathrm{ng} / \mathrm{ml}$ TGF $\beta 3$, and sub-G1 peak determined by FACS. Bars represent mean \pm S.E.M., $N=3$. (d) EpH4 cells were transfected with pEGFP and pTSC-22D1 isoform 1 cloned in the reverse or correct orientation, and treated with $5 \mathrm{ng} / \mathrm{ml} \mathrm{TGF} \beta 3$ for $72 \mathrm{~h}$. The sub-G1 peak was determined by FACS. Bars represent averages \pm S.E.M., $N=3 .{ }^{*} P<0.05,{ }^{* *} P<0.01$

development (reviewed in Daniel et al. ${ }^{37}$ ), and that TGF $\beta 3$ in particular is necessary for efficient induction of apoptosis during involution. ${ }^{11}$ We speculated that TGF $\beta$ might be responsible for the observed induction of TSC-22D1 during involution. The expression profiles of all the three isoforms of TGF $\beta$ (Figure 6a) showed that although both TGF $\beta 1$ and TGF $\beta 2$ were present at low levels throughout mammary gland development, only TGF $\beta 3$ had an RNA expression profile that suggested a possible relationship with the induction of TSC-22D1 on the first day of involution. Whereas TGF $\beta 1$ RNA levels increased at day 3 of involution, TGF $\beta 3$ was greatly elevated from day 1 until day 4 , strongly resembling the expression profile of TSC-22D1. We therefore investigated whether TGF $\beta 3$ could induce the TSC-22D1 isoform 2 expression in vitro. EpH4 cells were treated with $5 \mathrm{ng} / \mathrm{ml}$ of either TGF $\beta 1$ or TGF $\beta 3$ for $2 \mathrm{~h}$, and the expression of TSC22D1 was monitored by qRT-PCR. The 2 -h treatment time was determined to be the peak of the TSC-22D1 isoform 2 induction for both TGF $\beta 1$ and TGF $\beta 3$ in optimisation experiments (not shown). EpH4 cells contained low basal levels of both TSC22D1 isoforms under vehicle-control conditions. Both TGF $\beta 1$ and TGF $\beta 3$ were able to stimulate expression of the TSC-22D1 isoform 2; however, this effect was most pronounced in response to TGF $\beta 3$ (Figure 6b). No increased expression of isoform 1 was found in response to either TGF $\beta 1$ or TGF $\beta 3$. These data support the hypothesis that the TSC-22D1 isoform 2 can be induced by TGF $\beta 3$ in the involuting mammary gland, and furthermore indicate independent transcriptional control mechanisms for the two isoforms.

The TSC-22D1 isoform 2 has previously been shown to enhance TGF $\beta 1$-induced Smad transcriptional activity. ${ }^{20}$ To examine whether the TSC-22D1 isoform 2 could affect
TGF $\beta$-induced cell death, $\mathrm{EpH} 4$ cells were transfected with pEGFP-TSC-22D1 isoform 2 or with pEGFP alone, followed by treatment with $5 \mathrm{ng} / \mathrm{ml}$ TGF $\beta 1$ or TGF $\beta 3$ for $72 \mathrm{~h}$. The sub-G1 content of transfected cells was measured by FACS. Although isoform 2 showed the expected increase in TGF $\beta 3$-induced sub-G1 content, there was no effect on TGF $\beta 1$-treated cells at this time point (Figure 7a). The increase in TGF $\beta 3$-induced cell death was further confirmed using a Caspase $3 / 7$ assay (Promega, Madison, WI, USA) (Figure 7b). In contrast, knock down of the TSC-22D1 isoform 2 using specific miRNAs significantly reduced TGF $\beta 3$-induced cell death (Figure 7c). Similarly, overexpression of the TSC22D1 isoform 1 also significantly reduced the TGF $\beta 3$-induced cell death (Figure 7d).

\section{Discussion}

TSC-22D1 is a member of the leucine zipper superfamily and was previously shown to have a role during embryonic epithelial morphogenesis in Drosophila, ${ }^{14}$ chick $^{15}$ and mouse. ${ }^{19}$ However, this is the first report to implicate TSC-22D1 as a possible regulator of cell death in the mouse mammary gland during the lactation-to-involution switch. Furthermore, this is the first observation that the two isoforms of TSC-22D1 are differentially regulated, and have opposing effects on mammalian cell proliferation and viability.

Although TSC-22D1 isoform 1 levels were unchanged during mammary gland development, only the TSC-22D1 isoform 2 expression was highly increased during early mammary gland involution, paralleled by a strong increase in TSC-22D1 immune-reactivity in luminal epithelial cells, and in cells shed into the lumen. This links TSC-22 isoform 2 
expression to early cell death during the lactation-to-involution switch. Our in vitro data, which show that overexpression of the TSC-22D1 isoform 2 can indeed induce and enhance cell death in mammary epithelial cells, further suggest that isoform 2 could be directly involved in the induction of cell death during this developmental stage. Surprisingly, the TSC-22D1 isoform 2 was expressed as four distinct bands. As these four bands could also be detected when a cDNA for isoform 2 was expressed in MCF7 cells, these bands could represent different post-translational modifications. These bands showed different expression profiles, suggesting that the proteins have different activities in mammary epithelial cells, and only the $15-\mathrm{kDa}$ form was predominantly associated with early involution when cell death was induced. None of the other forms were detected at this time point. However, the 18- and $20-\mathrm{kDa}$ forms were the predominant forms during pregnancy and when the cDNA of TSC-22D1 isoform 2 was overexpressed in MCF7 cells, whereas the $15-\mathrm{kDa}$ band was the weakest. This indicates that various posttranscriptional modifications of isoform 2 occur under different conditions, which may possibly affect its function, and that the $15-\mathrm{kDa}$ form seems to be responsible for the cell death-inducing function of the TSC-22D1 isoform 2. This novel observation may explain why TSC-22D1 isoform 2 expression is not always associated with cell death in all tissues. ${ }^{14,19,20,24,25,27,34}$

Although reduced colony formation in TSC-22D1 isoform 2 overexpressing cells suggested an induction of either cell death or growth arrest, our FACS analysis showed that the TSC-22 isoform 2 induced cell death in mammary epithelial cells, with no apparent growth arrest as had been described in colon carcinoma cells. ${ }^{22}$ Overexpression of the TSC-22D1 isoform 1 exerted the opposite effect on the TSC-22 isoform 2, as it increased cell proliferation. Therefore, our data are in agreement with those recently observed for the Drosophila orthologue of TSC-22 domain proteins (bun). ${ }^{35,36}$ The long isoform of bun (bunA) was found to promote cellular growth and proliferation of Drosophila ovarian follicle cells and polar cells, whereas the small isoforms exerted no or only minimal effects. ${ }^{36}$ In addition, although bunA enhanced the growthpromoting activity of ribosomal protein S6 kinase when co-expressed in the dorsal compartment of the wing imaginal disc, the TSC-22D1 isoform 2 orthologues, bunB and bunC, antagonised this activity. ${ }^{35}$ The similarity between these results and our findings indicate a highly conserved function of the TSC-22D1 gene in both organisms. However, whereas mutations that deleted the small bun isoforms (orthologues of isoform 2 in mammals) exerted no effect on cell viability or proliferation, ${ }^{35}$ a knockdown of the TSC-22D1 isoform 2 in mammary epithelial cells increased colony formation and decreased TGF $\beta 3$-induced cell death, indicating that the isoform 2 has an important role in controlling cell survival in the mammary epithelial system under these conditions. Similarly, whereas bunA depletion in Drosophila S2 cells increased cell death, ${ }^{36}$ the TSC-22D1 isoform 1 did not seem to be necessary for cell survival in vitro, although this isoform reduced the cell death induced by TGF $\beta 3$. This novel observation of the opposing functions of the TSC-22D1 isoforms in mammalian cells may help explain the recent findings in TSC-22D1 knockout mice. Knocking out both isoforms induced cell proliferation in lymphocytes, but reduced the weights of the kidneys and hearts, ${ }^{34}$ indicating the possibility that functions of the different isoforms are dominant in different tissues. Unfortunately, the mammary glands of these knock out mice were not analysed.

The TSC-22D1 isoform 2 was previously shown to be expressed in epithelial cells at sites of the epithelialmesenchymal interaction, ${ }^{19}$ and bun was found to integrate opposing signalling pathways to set tissue boundaries. ${ }^{14}$ The expression of TSC-22D1 in myoepithelial cells is in agreement with these observations, and suggests that in the noninvoluting mammary gland, TSC-22D1 could be involved in the maintenance of the epithelial-stromal boundary, although the mechanism(s) for this are unknown. It is still unclear which isoform is predominantly expressed in the myoepithelium. Whereas our RT-PCR data of sorted mammary epithelial cells from an adult virgin mouse showed that isoform 2 RNA expression was the highest, western blots identified mostly isoform 1, with very low amounts of isoform 2 protein in mammary glands of virgin or pregnant mice. This could suggest that isoform 1 has higher protein stability or is more effectively translated. Certainly, the TSC-22D1 isoform 2 seems to have different functions in the myoepithelial and luminal epithelial cells, as major cell death only occurs during involution, when isoform 2 is upregulated in the luminal epithelium. It remains an open question whether the presence of isoform 1 in the myoepithelium antagonises the proapoptotic function of isoform 2 in these cells. Furthermore, only the 18- and 20-kDa forms of isoform 2 could be detected in the mammary glands of pregnant mice, but neither the 15nor $11-\mathrm{kDa}$ forms, again suggesting that post-translational modifications can alter the activity of isoform 2 .

$T S C-22 D 1$ was originally described as a TGF $\beta 1$-inducible gene, ${ }^{12}$ and TGF $\beta 3$ is involved in cell death during involution. ${ }^{11,37}$ In the involuting mammary gland, the TSC-22D1 expression profile was much more closely matched to that of TGF $\beta 3$ than to TGF $\beta 1$ or TGF $\beta 2$. Furthermore, we found that the TSC-22D1 isoform 2 was induced in cultured mammary epithelial cell lines treated with TGF $\beta 3$ to a greater extent than in cells treated with TGF $\beta 1$. In light of these results, and the fact that TGF $\beta$ proteins have multiple roles during mammary gland development, ${ }^{11,37}$ it is feasible that TGF $\beta 3$ is responsible for regulating the expression of the TSC-22D1 isoform 2 at the onset of involution. However, our results cannot exclude the possibility that factors other than, or in addition to, TGF $\beta 3$ might provide this function. This possibility is further strengthened by the finding that TGF $\beta 3$ is important for alveolar differentiation during late pregnancy, ${ }^{37}$ whereas no upregulation of the 11- and 15-kDa bands of the TSC-22D1 isoform 2 were observed during these developmental stages. It is possible that in a different microenvironment, such as that found at the end of pregnancy, TGF $\beta 3$ induces the 18- and $20-\mathrm{kDa}$ bands of the TSC-22D1 isoform 2, which may have functions associated with alveolar differentiation.

Further evidence for regulation of the TSC-22D1 isoform 2 by TGF $\beta 3$ is the similar localisation of both proteins. Indeed, TGF $\beta 3$ is localised to the myoepithelium of virgin mammary glands, ${ }^{38}$ and is induced in the lobuloalveolar epithelium during involution, ${ }^{11}$ thereby replicating the expression pattern reported in this study for TSC-22D1. Unfortunately, no 
material from TGF $\beta 3$-null mice from previously published studies was available, which would have allowed us to test for changes in TSC-22D1 isoform 2 expression during the mammary gland developmental cycle, and to determine the effect of the loss of such an apoptosis-inducing mechanism on involution.

The finding that the TSC-22D1 isoform 2 induced and potentiated TGF $\beta 3$-induced cell death further indicates a role of this protein in enabling the quick and extensive induction of cell death that occurred during involution. The action of the TSC-22D1 isoform 2 on TGF $\beta 3$-induced cell death may be due to its ability to bind to Smad4, a downstream target of $\operatorname{TGF} \beta$, and to increase the transcriptional activity of Smad ${ }^{20}$ (unpublished observation in $\mathrm{EpH} 4$ cells). In contrast, the TSC-22D1 isoform 1 was able to reduce the amount of TGF $\beta 3$-induced cell death and the transcriptional activity of Smad in response to TGF $\beta 3$ (unpublished observation).

In summary, we have identified the transcription factor, TSC-22D1, as a putative regulator of cell death during the first stage of mammary gland involution. Our results indicate that expression of the TSC-22D1 isoform 2 can be induced by TGF $\beta 3$ signalling in vitro to enhance a pro-apoptotic cascade. Moreover, we report that the TSC-22D1 isoform 1 has opposite functions in mammary epithelial cell lines to isoform 2 , inducing proliferation and reducing TGF $\beta 3$-induced cell death in vitro, thereby highlighting the need for researchers to specify the isoform studied. Further studies will need to establish the mechanism(s) of action of the two isoforms.

\section{Materials and Methods}

Microarray analysis. Complete details of sample preparation and the microarray analysis have been described previously. ${ }^{7}$ Briefly, the fourth (inguinal) mammary glands of Balb/C mice were harvested at the following developmental stages: virgin (weeks 6, 10 and 12), pregnancy (days 1, 2, 3, 8.5, 12.5, 14.5 and 17.5), lactation (days 1, 3 and 7) and involution (days 1, 2, 3, 4 and 20). For involution samples, mouse pups were removed after 7 days of lactation. Total RNA was prepared using Trizol (Invitrogen, Paisley, UK), and CRNA was produced according to the method recommended by Affymetrix. Labelled CRNA was hybridised to the Affymetrix MG-U74Av2 chip. All experiments were carried out in triplicate with RNA obtained from three individual mice. Data were analysed using the Affymetrix Data Mining Tool.

Western blot analysis. Protein extracts were prepared from 2-3-mm strips of the fourth (inguinal) mammary gland and extracted by crushing the tissue in liquid nitrogen using a mortar and pestle on dry ice. The resulting powder was then transferred into a glass homogeniser and re-suspended in lysis buffer $(50 \mathrm{mM}$ Tris $\mathrm{pH}$ $7.5,150 \mathrm{mM} \mathrm{NaCl}, 5 \mathrm{mM}$ EDTA, 1\% IPEGAL-CA630, phosphatase inhibitor cocktail II (Sigma-Aldrich, Poole, UK), Complete Mini protease inhibitor cocktail (Roche Applied Science, Lewes, UK)), incubated for $10 \mathrm{~min}$ at $4^{\circ} \mathrm{C}$ and centrifuged for $10 \mathrm{~min}$ at $20000 \mathrm{~g}$ at $4^{\circ} \mathrm{C}$. Protein concentrations were estimated using the BCA method (Pierce Biotechnology, Rockford, IL, USA). In all, 50-100 $\mu$ g of protein was separated under denaturing and reducing conditions on a 4-12\% Bis-Tris NuPage gel (Invitrogen) in the MES-SDS buffer. Separated proteins were transferred onto nitrocellulose membrane (Schleicher \& Schuell, Dassel, Germany) and stained using Ponceau S to verify the complete transfer. Antibodies used were the rabbit polyclonal antibody to human TSC22D1 (Proteintech Group, diluted 1:500), the goat polyclonal antibody to mouse/rat TSC-22D1 (Research and Development, Abingdon, UK, diluted 1:500) and a goat polyclonal antibody to actin (Amersham, Chalfont St. Giles, UK, diluted 1:1000). Proteins were detected by chemiluminescence using ECL reagent (Amersham).

qRT-PCR. RNA isolation was carried out as described previously. ${ }^{7}$ RNA was DNAse treated (DNA-free; Ambion, Huntingdon, UK) according to the manufacturer's protocol, and $\mathrm{CDNA}$ was produced from $1 \mu \mathrm{g}$ of RNA using random primers (Invitrogen) and Transcriptor reverse transcriptase (Roche Applied Science) according to the manufacturer's instructions. A volume of $1 \mu \mathrm{l}$ of cDNA was used for the PCR reaction using Universal Probe Library assays designed on the Roche Applied Science website as follows:

Murine TSC-22D1 isoform 1 primers: 5'-GCCAGTGACTCAAAATCCAAC-3'; 5'-GAGGACAATGCTGCTTGAAA-3'; probe 66 .

Murine TSC-22D1 isoform 2 primers: $5^{\prime}$-CAGCTAGGCGGTTTATCTAGTTT-3'; $5^{\prime}$-GCAATTGCAGCCAAATTAAAA-3'; probe 64.

Murine $\beta$-actin primers: $5^{\prime}$-AAGGCCAACCGTGAAAAGAT-3'; $5^{\prime}$-GTGGTACGA CCAGAGGCATAC- $3^{\prime}$; probe 56 .

Murine cytokeratin (KRT) 18 primers: 5'-AGATGACACCAACATCACAAGG-3'; reverse: 5'-TCCAGACCTTGGACTTCCTC-3'; probe 78 .

The assays were set-up according to the manufacturer's instructions, using LightCycler 480 Probes Master $(2 \times$, Roche Applied Science), and the reactions were performed on a LightCycler 480 Real-Time PCR system (Roche Applied Science). Data analysis was carried out using LightCycler 480 software, version 1.5. $C_{t}$ values for each TSC-22D1 isoform were normalised to $C_{t}$ values of either $\beta$-actin or KRT 18 as mentioned in the figures. Samples without reverse transcriptase were used as negative controls. Each sample analysis was carried out in triplicate wells.

Immunohistochemistry. IHC was performed using the goat polyclonal primary antibody against murine TSC-22D1 (R\&D, diluted 1:100). Antigen retrieval was carried out in $1 \mathrm{mM}$ EDTA (pH 8.0). Paraffin-embedded tissue sections were stained using the ImmPRESS anti-goat Ig kit (Vector Laboratories, Peterborough, UK) and visualised by $3,3^{\prime}$-diaminobenzidine tetrahydrochloride (DABplus, Dako, Ely, UK). Stained sections were counterstained with haematoxylin.

Preparation and flow cytometry of mammary cell subpopulations. Fourth mammary fat pads were harvested from 10-week-old virgin FVB mice. Single mammary cell suspensions were prepared as described previously. ${ }^{32}$ Mammary cell suspensions at $10^{6}$ cells per $\mathrm{ml}$ were stained with antiCD24-FITC (clone M1/69, BD Biosciences, Oxford, UK, $0.5 \mu \mathrm{g} / \mathrm{ml}$ ), anti-CD45-PE-Cy5 (clone 30-F11, BD Biosciences, $0.25 \mu \mathrm{g} / \mathrm{ml}$ ) and anti-Sca-1-PE (clone D7, BD Biosciences, $0.5 \mu \mathrm{g} / \mathrm{ml}$ ) as described previously. ${ }^{32}$ Cells were sorted at low pressure (20 psi using a $100 \mu \mathrm{m}$ nozzle) on a FACSAria (Becton Dickenson, Oxford, UK) equipped with violet $(404 \mathrm{~nm})$, blue $(488 \mathrm{~nm})$, green $(532 \mathrm{~nm})$, yellow $(561 \mathrm{~nm})$ and red $(635 \mathrm{~nm})$ lasers. Both cell sample and collection tubes were maintained at $4^{\circ} \mathrm{C}$ Single stained samples were used as compensation controls. Dead cells, $\mathrm{CD}^{+} 5^{+}$leukocytes and non-single cells were excluded. Cells were sorted into CD24 ${ }^{+/ \text {Low }}$ Sca- $1^{-}$(basal/ myoepithelial), $\mathrm{CD} 24^{+/ \text {High }} \mathrm{Sca}-1^{-}$(luminal oestrogen receptor negative) and $\mathrm{CD} 24^{+/ \text {High }} \mathrm{Sca}-1^{+}$(luminal oestrogen receptor positive) fractions. Freshly sorted mammary epithelial sub-populations were re-suspended in RLT buffer (Qiagen, Crawley, West Sussex, UK) and stored at $-80^{\circ} \mathrm{C}$ until required for RNA extraction.

Cell culture. The EpH4 mouse mammary gland cell line (clone K6) was kindly provided by Walter Birchmeier (Max Delbruck Centre for Molecular Medicine, Berlin, Germany). The MCF-7 human breast cancer cell line and HEK293T/17 were obtained from the ATCC (LGC Standards, Teddington, UK). Both cell lines were maintained in DMEM (Invitrogen) supplemented with $10 \% \mathrm{FBS}$ and grown at $37^{\circ} \mathrm{C}$ with $5 \% \mathrm{CO}_{2}$ in a humidified atmosphere. Cultures were serum starved overnight and treated with either TGF $\beta 1$ or TGF $\beta 3$ (Peprotech, London, UK) at a final concentration of $5 \mathrm{ng} / \mathrm{ml}$ and samples were collected at the indicated time points.

Transfections. EpH4 cells were transfected using Lipofectamine LTX and Plus reagent (Invitrogen) according to the manufacturer's instructions. MCF-7 cells were transfected using Lipofectamine 2000 (Invitrogen) according to the manufacturer's instructions, but the medium was changed $4 \mathrm{~h}$ after transfection to avoid cytotoxicity. pCMV-Sport-TSC-22 (human isoform 2, IMAGE clone 3850392) and PAsc-YXTSC-22 (murine isoform 1, IMAGE clone 6409347) were obtained from HGMP (Cambridge, UK). TSC-22D1 isoform 1 was then sub-cloned into pcDNA3 (Invitrogen) using Notl, and the orientation of the insert was checked. pCMV-Sport6 was obtained from Invitrogen. $\mathrm{pSV}_{2} \mathrm{NeO}, \mathrm{pEN}$-TTmirc3 and pSLIK-Neo were obtained from ATCC (LGC Standards). pmiRNAs were synthesised using the BLOCK-iT technology (Invitrogen) according to the manufacturer's instructions, with the following miRNA sequences:

miR-1:5'TGCTGTAAACTCCTAGATCCATCGCCGTTTTGGCCACTGACTGAC GGCGATGGCTAGGAGTTTA-3'; 
miR-2: 5 '-TGCTGATCGCCACTGGTCTACACCATGTTTTGGCCACTGACTGA CATGGTGTACCAGTGGCGAT-3';

miR-3: 5'-TGCTGTATGCTAGCAGCATTAGGGATGTTTTGGCCACTGACTGA CATCCCTAACTGCTAGCATA-3';

miR-4: 5'-TGCTGTAACAACACTGGTAACTCCAGGTITTGGCCACTGACTGAC CTGGAGTTCAGTGTTGTTA-3';

pmiR-NEG was provided in the kit. pMDLg/pRRE, pRSV-Rev and pCMV-VSV-G were obtained from Addgene Inc., Cambridge, MA, USA.

Generation of stable cell lines. The entry vector pEN-TTmirc2 was used, and the miRNA sequences from the Block-iT vectors described above were cloned into it using enzymes $\mathrm{Ncol}$ and $\mathrm{Xbal}$. The miRNA sequences and TT promoter were then cloned into the vector pSLIK-Neo using LB Clonase (Invitrogen). The SLIKmiRNA vectors were transfected into HEK293T/17 cells, together with pMDLg/ pRRE, pRSV-Rev and pCMV-VSV-G, to allow the generation of virus particles. The virus particles were used to transduce $\mathrm{EpH} 4$ cells, which were selected using $1 \mathrm{mg} / \mathrm{ml} \mathrm{G} 418$ (Sigma-Aldrich). Before each experiment, the cell lines were treated with $1 \mu \mathrm{g} / \mathrm{ml}$ doxycycline for $72 \mathrm{~h}$ to induce miRNA expression and for the knockdown of TSC-22D1.

Colony assays. Colony assays were performed to determine changes in cell proliferation and/or survival. Cells were plated at a low density and transfected as indicated, and treatment with selective antibiotics (G418, Sigma-Aldrich, $500 \mu \mathrm{g} / \mathrm{ml}$ for CMV plasmids, and blasticidin, Sigma-Aldrich, $6 \mu \mathrm{g} / \mathrm{ml}$ for pmiR plasmids) was started after $48 \mathrm{~h}$ to eliminate non-transfected cells. The medium containing antibiotic was changed every 2 days until the colonies were ready for staining. Culture dishes were stained with Giemsa (Sigma-Aldrich), rinsed in several washes of PBS and allowed to dry.

FACS. Cell cycle determination was performed as previously described. ${ }^{39}$ Briefly, cells were collected at the indicated time points, and fixed in methanol at $-20^{\circ} \mathrm{C}$. The cells were then stained with $50 \mu \mathrm{g} / \mathrm{ml}$ propidium iodide (Sigma-Aldrich) and $50 \mu \mathrm{g} / \mathrm{ml}$ RNase A (Sigma-Aldrich) for $30 \mathrm{~min}$ and the cell cycle was analysed only in transfected cells (green fluorescent protein (GFP) positive) by flow cytometry (FACSCalibur, BD Biosciences, and associated CellQuest software).

BrdU assay. Cell proliferation was assayed using a BrdU colorimetric ELISA (Roche Applied Science). EpH4 cells, transfected as indicated, were serum starved overnight and incubated for $4 \mathrm{~h}$ with BrdU, and the incorporation rate measured according to the manufacturer's instructions on a MR7000 microplate reader (Dynatech, Billinghurst, UK).

Statistical analysis. Depending on the number of sample groups and independent variables compared, Student's unpaired two-tailed $t$-test (comparing two sample groups), ANOVA-1 (comparing more than 2 sample groups) or ANOVA-2 (comparing more than two sample groups, with two independent variables) was used. For ANOVAs, Tukey's test was used for post hoc analysis. $P$-values are represented as ${ }^{*} P<0.05,{ }^{* *} P<0.01$ and ${ }^{* * *} P<0.001$.

Acknowledgements. We thank Dr. Hitoshi Kawamata, Dr. Adam West and Dr. Kiyoshi Nagata for reagents, Rod Ferrier and Anthony Cheung for technical support, and Dr. Gareth Inman for many helpful discussions. This work was supported by a Breakthrough Breast Cancer programme grant (BG) and a Breast Cancer Campaign grant (TS).

1. Richert MM, Schwertfeger KL, Ryder JW, Anderson SM. An atlas of mouse mammary gland development. J Mammary Gland Biol Neoplasia 2000; 5: 227-241.

2. Lund LR, Romer J, Thomasset N, Solberg H, Pyke C, Bissell MJ et al. Two distinct phases of apoptosis in mammary gland involution: proteinase-independent and -dependent pathways. Development 1996; 122: 181-193.

3. Stein T, Salomonis N, Gusterson BA. Mammary gland involution as a multi-step process. J Mammary Gland Biol Neoplasia 2007; 12: 25-35.

4. Li M, Hu J, Heermeier K, Hennighausen L, Furth PA. Apoptosis and remodeling of mammary gland tissue during involution proceeds through p53-independent pathways. Cell Growth Differ 1996; 7: 13-20.

5. Li M, Liu X, Robinson G, Bar-Peled U, Wagner KU, Young WS et al. Mammary-derived signals activate programmed cell death during the first stage of mammary gland involution. Proc Natl Acad Sci USA 1997; 94: 3425-3430.
6. Monks J, Geske FJ, Lehman L, Fadok VA. Do inflammatory cells participate in mammary gland involution? J Mammary Gland Biol Neoplasia 2002; 7: 163-176.

7. Stein T, Morris JS, Davies CR, Weber-Hall SJ, Duffy MA, Heath VJ et al. Involution of the mouse mammary gland is associated with an immune cascade and an acute-phase response, involving LBP, CD14 and STAT3. Breast Cancer Res 2004; 6: R75-R91.

8. Humphreys RC, Bierie B, Zhao L, Raz R, Levy D, Hennighausen L. Deletion of Stat3 blocks mammary gland involution and extends functional competence of the secretory epithelium in the absence of lactogenic stimuli. Endocrinology 2002; 143: 3641-3650.

9. Thangaraju M, Rudelius M, Bierie B, Raffeld M, Sharan S, Hennighausen $L$ et al. C/EBPdelta is a crucial regulator of pro-apoptotic gene expression during mammary gland involution. Development 2005; 132: 4675-4685.

10. Merto GR, Cella N, Hynes NE. Apoptosis is accompanied by changes in Bcl-2 and Bax expression, induced by loss of attachment, and inhibited by specific extracellular matrix proteins in mammary epithelial cells. Cell Growth Differ 1997; 8: 251-260.

11. Nguyen AV, Pollard JW. Transforming growth factor beta 3 induces cell death during the first stage of mammary gland involution. Development 2000; 127: 3107-3118.

12. Shibanuma M, Kuroki T, Nose K. Isolation of a gene encoding a putative leucine zipper structure that is induced by transforming growth factor beta 1 and other growth factors. J Biol Chem 1992; 267: 10219-10224.

13. Ghedin E, Wang S, Spiro D, Caler E, Zhao Q, Crabtree J et al. Draft genome of the filarial nematode parasite Brugia malayi. Science 2007; 317: 1756-1760.

14. Dobens LL, Peterson JS, Treisman J, Raftery LA. Drosophila bunched integrates opposing DPP and EGF signals to set the operculum boundary. Development 2000; 127: 745-754.

15. Dohrmann CE, Noramly S, Raftery LA, Morgan BA. Opposing effects on TSC-22 expression by BMP and receptor tyrosine kinase signals in the developing feather tract. Dev Dyn 2002; 223: 85-95.

16. Fiol DF, Kultz D. Rapid hyperosmotic coinduction of two tilapia (Oreochromis mossambicus) transcription factors in gill cells. Proc Natl Acad Sci USA 2005; 102: 927-932.

17. Hashiguchi A, Okabayashi K, Asashima M. Role of TSC-22 during early embryogenesis in Xenopus laevis. Dev Growth Differ 2004; 46: 535-544.

18. Uchida D, Kawamata H, Omotehara F, Miwa Y, Hino S, Begum NM et al. Over-expression of TSC-22 (TGF-beta stimulated clone-22) markedly enhances 5-fluorouracil-induced apoptosis in a human salivary gland cancer cell line. Lab Invest 2000; 80: 955-963.

19. Dohrmann CE, Belaoussoff M, Raftery LA. Dynamic expression of TSC-22 at sites of epithelial-mesenchymal interactions during mouse development. Mech Dev 1999; 84: 147-151.

20. Choi SJ, Moon JH, Ahn YW, Ahn JH, Kim DU, Han TH. Tsc-22 enhances TGF-beta signaling by associating with Smad4 and induces erythroid cell differentiation. Mol Cell Biochem 2005; 271: 23-28.

21. Kawamata $\mathrm{H}$, Nakashiro K, Uchida D, Hino S, Omotehara F, Yoshida $\mathrm{H}$ et al. Induction of TSC-22 by treatment with a new anti-cancer drug, vesnarinone, in a human salivary gland cancer cell. Br J Cancer 1998; 77: 71-78.

22. Gupta RA, Sarraf P, Mueller E, Brockman JA, Prusakiewicz JJ, Eng C et al. Peroxisome proliferator-activated receptor gamma-mediated differentiation: a mutation in colon cancer cells reveals divergent and cell type-specific mechanisms. J Biol Chem 2003; 278: 22669-22677.

23. Hino S, Kawamata H, Uchida D, Omotehara F, Miwa Y, Begum NM et al. Nuclear translocation of TSC-22 (TGF-beta-stimulated clone-22) concomitant with apoptosis: TSC-22 as a putative transcriptional regulator. Biochem Biophys Res Commun 2000; 278: 659-664.

24. Dobens LL, Hsu T, Twombly V, Gelbart WM, Raftery LA, Kafatos FC. The Drosophila bunched gene is a homologue of the growth factor stimulated mammalian TSC-22 sequence and is required during oogenesis. Mech Dev 1997; 65: 197-208.

25. Treisman JE, Lai ZC, Rubin GM. Shortsighted acts in the decapentaplegic pathway in Drosophila eye development and has homology to a mouse TGF-beta-responsive gene. Development 1995; 121: 2835-2845.

26. Jay P, Ji JW, Marsollier C, Taviaux S, Berge-Lefranc JL, Berta P. Cloning of the human homologue of the TGF beta-stimulated clone 22 gene. Biochem Biophys Res Commun 1996; 222: 821-826.

27. Kester HA, Ward-van Oostwaard TM, Goumans MJ, van Rooijen MA, van Der Saag PT, van Der Burg B et al. Expression of TGF-beta stimulated clone-22 (TSC-22) in mouse development and TGF-beta signalling. Dev Dyn 2000; 218: 563-572.

28. Ohta S, Shimekake $Y$, Nagata K. Molecular cloning and characterization of a transcription factor for the C-type natriuretic peptide gene promoter. Eur J Biochem 1996; 242: 460-466.

29. Kester HA, Blanchetot C, den Hertog J, van der Saag PT, van der Burg B. Transforming growth factor-beta-stimulated clone-22 is a member of a family of leucine zipper proteins that can homo- and heterodimerize and has transcriptional repressor activity. J Biol Chem 1999; 274: 27439-27447.

30. Gordon KE, Binas B, Chapman RS, Kurian KM, Clarkson RW, Clark AJ et al. A novel cell culture model for studying differentiation and apoptosis in the mouse mammary gland. Breast Cancer Res 2000; 2: 222-235.

31. Sleeman KE, Kendrick H, Ashworth A, Isacke CM, Smalley MJ. CD24 staining of mouse mammary gland cells defines luminal epithelial, myoepithelial/basal and non-epithelial cells. Breast Cancer Res 2006; 8: R7.

32. Sleeman KE, Kendrick H, Robertson D, Isacke CM, Ashworth A, Smalley MJ. Dissociation of estrogen receptor expression and in vivo stem cell activity in the mammary gland. J Cell Biol 2007; 176: 19-26. 
33. Nakashiro K, Kawamata H, Hino S, Uchida D, Miwa Y, Hamano $\mathrm{H}$ et al. Down-regulation of TSC-22 (transforming growth factor beta-stimulated clone 22) markedly enhances the growth of a human salivary gland cancer cell line in vitro and in vivo. Cancer Res 1998; 58 : 549-555.

34. Yu J, Ershler M, Yu L, Wei M, Hackanson B, Yokohama A et al. TSC-22 contributes to hematopoietic precursor cell proliferation and repopulation and is epigenetically silenced in large granular lymphocyte leukemia. Blood 2009; 113: 5558-5567.

35. Gluderer S, Oldham S, Rintelen F, Sulzer A, Schutt C, Wu X et al. Bunched, the Drosophila homolog of the mammalian tumor suppressor TSC-22, promotes cellular growth. BMC Dev Biol 2008; 8: 10 .
36. Wu X, Yamada-Mabuchi M, Morris EJ, Tanwar PS, Dobens L, Gluderer S et al. The Drosophila homolog of human tumor suppressor TSC-22 promotes cellular growth, proliferation, and survival. Proc Natl Acad Sci USA 2008; 105: 5414-5419.

37. Daniel CW, Robinson S, Silberstein GB. The transforming growth factors beta in development and functional differentiation of the mouse mammary gland. Adv Exp Med Biol 2001; 501: 61-70.

38. Robinson SD, Silberstein GB, Roberts AB, Flanders KC, Daniel CW. Regulated expression and growth inhibitory effects of transforming growth factor-beta isoforms in mouse mammary gland development. Development 1991; 113: 867-878.

39. Ryan KM, Ernst MK, Rice NR, Vousden KH. Role of NF-kappaB in p53-mediated programmed cell death. Nature 2000; 404: 892-897.

Supplementary Information accompanies the paper on Cell Death and Differentiation website (http://www.nature.com/cdd) 